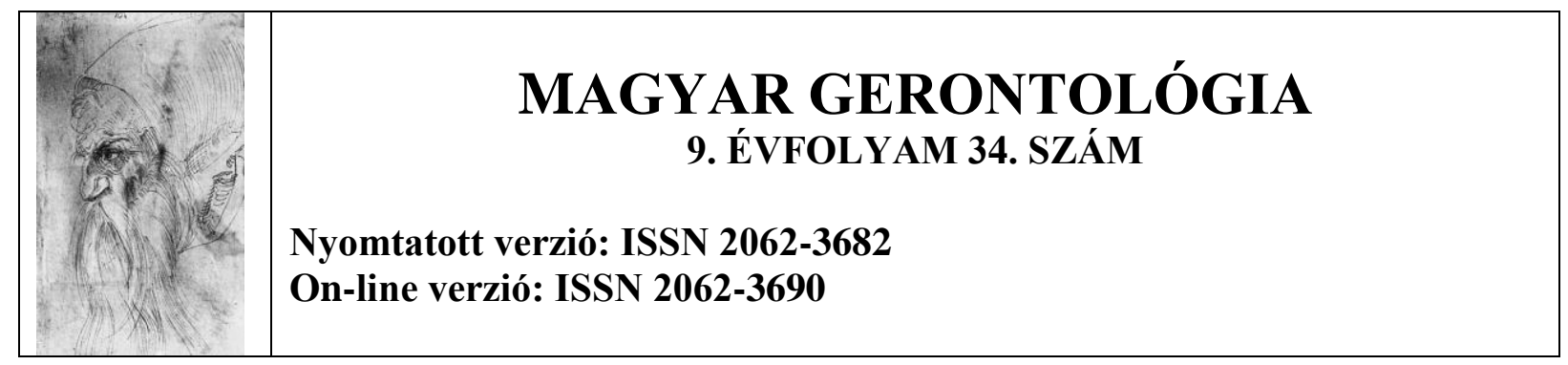

\title{
A házi segítségnyújtás szabályozásainak hatása a Nyíregyházi Szociális Gondozási Központban ${ }^{6}$
}

\begin{abstract}
Szabó Rita Zsuzsa
Kulcsszavak: szociális gondozás, házi segítségnyújtás, idősek

\section{Összefoglalás}

Előadásomban első részében felvázolom Nyíregyháza város demográfiai körképét különös hangsúlyt fektetve az idősek arányára, nemi eloszlására és életkörülményeire. Ezután kitérek a Nyíregyházi Gondozási Központ idősellátásra vonatkozó alapszolgáltatásaira, és ezek müködésének feltételeire. Ezután kerül sor az előadás fő témájának, a házi segítségnyújtás törvényi és intézményi hátterének bemutatására, a törvényi szabályozás módosításából fakadó problémákra.
\end{abstract}

\section{Bevezetés}

Nyíregyháza Megyei Jogú Város közel 120.000 fös lakónépességével országunk hetedik legnagyobb városa. A lakosság korszerkezete 1980 óta szignifikáns eltéréseket mutat a korábbi évtizedekhez képest. A születések számának visszaesése miatt a gyermekkorú népesség száma csökken, a születéskor várható élettartam növekedése ezzel szemben a 65 év feletti lakosság számának permanens emelkedését vonja maga után. A korstruktúra változása az életminőséget is befolyásolja, egyebek mellett a lakosság egészségi állapotára gyakorolt hatása révén (Jóna és Jávorné Erdei, 2012). A statisztikai adatok szerint Nyíregyháza lakónépességén belül a 65 év felettiek aránya meghaladja a 14\%-ot.

Közismert tény, hogy társadalmunkban a népesség egyszerre fogy és öregszik, ezen folyamatok nagy mértékben befolyásolják a magyarországi idősek helyzetét. A korábbi időszakokhoz képest ma sokkal több ember él meg magasabb életkort, ami több betegséget, elmagányosodást jelent. Ezek következménye a gondozásra, ápolásra való igény fokozódása.

\footnotetext{
${ }^{6}$ Elhangzott a Nyíregyházi Gerontológiai Napok 2016. évi konferenciáján.
} 
Emellett a születések számának csökkenése, az országon belüli migráció, valamint a külföldön történő munkavállalási kedv fokozódása mind-mind olyan tényezők, melyek befolyásolják az egyszemélyes háztartások számának folyamatos emelkedését, és a természetes támogató rendszerek meggyengüléséhez vezetnek.

A férfiak és a nők korstruktúrája markánsan különbözik. Ez azt jelenti, hogy a város időskorú lakosságának közel kétharmada a gyengébbik nemhez tartozik, így az idősek által lakott egyszemélyes háztartásokban magasabb számban fordulnak elő nők. Nyíregyháza női lakosságának öregedési indexe 120, szemben a férfi lakosság 63-as indexszámával.

A családi állapot szerinti struktúra is folyamatos változást mutat. 1980 és 2010 között a nőtlen férfiak és a hajadon nők száma egyaránt közel a duplájára, az elváltaké több, mint háromszorosára emelkedett városunkban (Malakucziné Póka, 2012).

\section{Nyíregyházi Szociális Gondozási Központ alapszolgáltatásai}

Nyíregyháza Megyei Jogú Város területén a szociális szolgáltatások rendszere szinte hiánytalanul kiépült. A Nyíregyházi Szociális Gondozási Központ ezen a területen jelentős szerepet vállal 1993 óta. A Központ az 1993. évi III. szociális igazgatásról és szociális ellátásokról szóló törvény értelmében az alábbi szociális alapszolgáltatásokat és szakosított ellátási formákat biztosítja:

Szociális alapszolgáltatás keretében:

- Házi segítségnyújtás

- Jelzőrendszeres házi segítségnyújtás

- Idősek nappali ellátása

- Étkeztetés

- Pszichiátriai betegek részére nyújtott közösségi alapellátás

- Támogató szolgáltatás

- Fogyatékos személyek nappali ellátása (intézményi jogviszonyhoz kötött fejlesztő foglalkoztatás)

- Pszichiátriai betegek nappali ellátása

Szakositott ellátás keretében:

- Idősek otthona (Barna, 2017) 
Az intézmény által biztosított szociális alapszolgáltatások közül a házi segítségnyújtás szakfeladat az, melynek keretében a legtöbb személy ellátását biztosítjuk. Házi segítségnyújtás keretében azokat a személyeket látjuk el, akik saját otthonukban önmaguk ellátására részben képesek, szükségletvizsgálatuk alapján ellátásuk indokolt, kérik és elfogadják a segítségnyújtást.

A Nyíregyházi Szociális Gondozási Központ 7 házigondozó körzetet müködtet Nyíregyháza város területén. Jelenleg közel 600 fő szolgáltatást igénybe vevő személy saját lakókörnyezetében biztosítjuk az önálló életvitel fenntartása érdekében szükséges ellátást 75 szakképzett gondozónő segítségével (Szilvásiné Bojda, 2017).

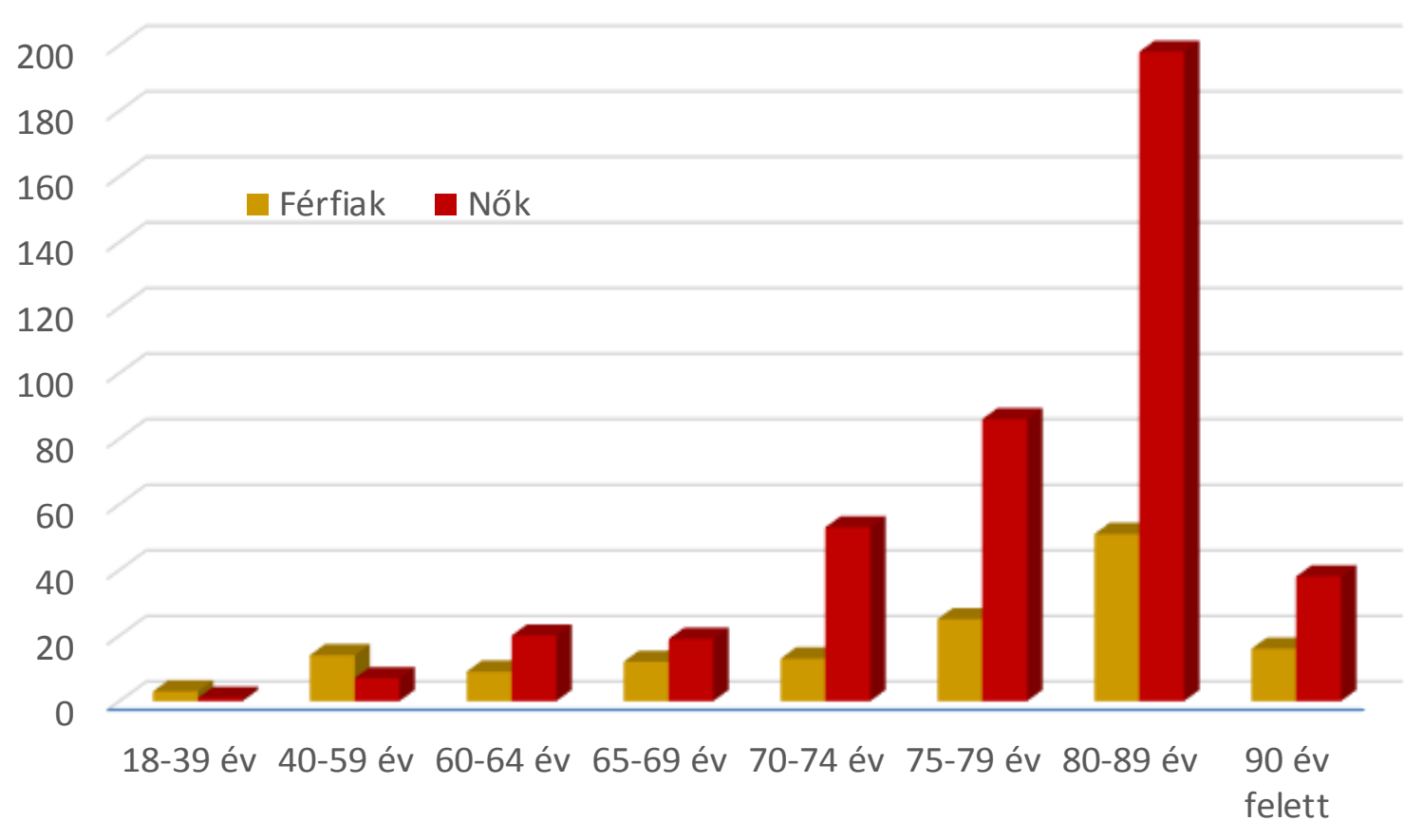

1. ábra: Az ellátottak kor és nem szerinti megoszlása 2017. május 31-én

\section{Házi segítségnyújtás a Nyíregyházi Szociális Gondozási Központban}

Az utóbbi években a házi segítségnyújtás müködését szabályozó törvényi változások folyamatosan újabb és újabb feladatokat róttak a szakemberekre. Jelenleg két szolgáltatási elemre, személyi gondozásra és szociális segítésre válik szét a szolgáltatás. Ezen szolgáltatási elemek tartalmát központilag határozták meg, csakúgy, mint a jogosultsági feltételeket és az ezek alapján lehívható állami támogatás mértékét. A szociális segítésre jogosultságot szerzett ellátottak szükségleteinek kielégítése alacsonyabb szinten történik, hiszen egészségi állapotuk 
nem indokolja a szakember által történő, a szolgáltatás tartalmához mérten teljes körünek számító ellátást.

Hogy mit jelent ez a gyakorlatban? Az évek óta szolgáltatásban részesülő idősek számára, akik a 36/2007. SZMM. rendelet 2015. év végi módosítása nyomán csak szociális segítésre szereztek jogosultságot, sok esetben érthetetlen az a tény, hogy bizonyos tevékenységek tekintetében (például: vérnyomás és vércukor mérése, körömápolás) nem kérhetik munkatársaink segítségét. A korábbi években természetes volt, hogy hiányzó részképességeik függvényében teljes körü ellátásban részesítettük őket.

A differenciált normatív állami támogatás miatt a szolgáltatók eltérő térítési díj ellenében láthatják el a személyi gondozásra, illetve a szociális segítésre jogosult ellátottakat, szociális segítés esetében akár szakképzetlen munkaerőt foglalkoztatva. Az igénybevételt megelőzően a szolgáltatás iránti kérelem alapján az intézmény szakemberei végzik el az igénylő gondozási szükségletének vizsgálatát. Ennek keretében kerül megállapításra, hogy az ellátást igénylő esetében szociális segítés vagy személyi gondozás indokolt. A müködést engedélyező szerv szociális igazgatási bírságot szabhat ki az intézményvezetővel, illetve a gondozási szükséglet vizsgálatát tényleges végző személlyel szemben, ha a házi segítségnyújtás esetén nem a valóságnak megfelelően került megállapításra, hogy az ellátott számára szociális segítés vagy személyi gondozás indokolt-e. A szolgáltatók szakemberei a városban müködő háziorvosokkal együttmüködve végzik a gondozási szükséglet vizsgálatát, állapot változás esetén annak felülvizsgálatát. A háziorvosokban számos esetben merül fel, hogy őket is terhelheti-e valamilyen bírság, illetve aggályaikat fejezték ki azzal kapcsolatban is, hogy az orvos-beteg viszonyt bizonyos esetekben negatív irányban befolyásolhatják az általuk adott pontszámok. Az értékelő adatlap másolati példányát ugyanis az ellátott részére át kell adni.

A személyes gondoskodást nyújtó ellátásokért a szolgáltatást igénybe vevőknek térítési díjat kell fizetni. Ennek mértékét Nyíregyháza Megyei Jogú Város Közgyülése helyi rendeletben határozza meg. A fentiek alapján házi segítségnyújtás személyi gondozás szolgáltatási elemének esetében jelenleg négy, míg a szociális segítésre jogosult ellátottak esetében két díjfizetési kategória az irányadó. A havonta fizetendő térítési díj nem haladhatja meg az ellátott rendszeres havi jövedelmének 25\%-át házi segítségnyújtás esetében.

Az ellátottak harmada rendelkezik $100.000 \mathrm{Ft}$ alatti rendszeres havi jövedelemmel. A relatív lakásnagyság, a rendszeres havi kiadások változása nagyban befolyásolják az idősek életminőségét, így sokuk igyekszik a havi rendszeres kiadásait minimalizálni. Az egyszemélyes háztartások száma folyamatosan emelkedik, egyre több idős marad korábbi, 
sokszor egy fö számára irreálisan nagy alapterületü, esetenként gazdaságosan nem fenntartható ingatlanban, így mindennapi megélhetésük, a megemelkedett rezsi és gyógyszerköltségek megfizetése komoly problémát jelent. Ennek tudható be az a tény is, hogy az ellátottak az esetek túlnyomó többségében a tényleges szükségletüktől eltérően, kevesebb időben veszik igénybe a házi segítségnyújtás szolgáltatást.

Mindemellett gyakorlatilag arra sincs lehetőség, hogy a finanszírozási szempontokat figyelmen kívül hagyva kizárólag az ellátottak kérését, igényeit és szükségleteit figyelembe véve biztosítsuk ellátásukat. Munkánk során egyre gyakrabban szembesülünk azzal, hogy a természetes támogató rendszerek vagy nem funkcionálnak megfelelően (vidéken, külföldön élő hozzátartozók, megromlott családi kapcsolatok) vagy teljes egészében hiányoznak. Ezen tényezők nagyban befolyásolják az idősek gondozás iránti igényét és a részükről felmerülő megoldásra váró problémákat, ellátandó feladatokat. Mindennapossá váltak az olyan megoldásra váró teendők, (például kertes házak esetében a zöld területek gondozása) amelyek elvégzése nem tartozik munkatársaink kompetenciái közé, azonban az idős ellátottak azok közvetett megoldását, vagy az abban való közremüködést más külső segítség híján a szolgálattól várják.

\section{Következtetések}

Az idős lakosságot érintő társadalmi folyamatok előre vetítik, hogy az egyéni felelősségvállalás mellett a jövőben is kiemelt szerephez jut majd a szociális ellátórendszer, és annak fejlesztése. Hogy milyen változások elé állítja a szolgáltatókat az elkövetkező időszak, még nem lehet tudni.

Fontos, hogy ezeket a társadalmi változásokat, a jövőben felmerülő megoldásra váró problémákat olyan szakemberek kezelhessék, akik korszerü ismeretekkel felvértezve, minőségi szolgáltatást nyújtva segíthetik a szépkorúakat. A tapasztalatok azt mutatják, hogy az egyre gyarapodó létszámú időskorú lakosság egyik leghumánusabb ellátási formája, a házi segítségnyújtás, egyre több ember számára jelenti majd a békésebb időskort a megszokott, biztonságot nyújtó saját környezetben.

\section{Irodalomjegyzék}

Barna H. (2017): Idősek nappali ellátása a Nyíregyházi Szociális Gondozási Központban. Magyar Gerontológia, 9 (34): 2-10.

Jóna Gy. És Jávorné Erdei R. (2012): A szubjektív egészségi állapot meghatározó tényezői Nyíregyházán. Acta Medicinae et Sociologica, 3 (3): 99-116. 
Malakucziné Póka M. (2012): Nyíregyháza lakosságának főbb demográfiai jellemzői. Acta Medicinae et Sociologica, 3 (3): 11-32.

Szilvásiné Bojda M. (2017): Intézményen belüli szakápolás a Nyíregyházi Szociális Gondozási Központ idősek otthonában. Magyar Gerontológia, 9 (34): 11-17.

\section{Szerzö:}

Szabó Rita Zsuzsa

okleveles egészségügyi szociális munkás, szociálgerontológus

Nyíregyházi Szociális Gondozási Központ 